\title{
Occurrence and Epidemiology of Fannia Spp. (Diptera: Fanniidae) in Laying Poultry Farms in State of Minas Gerais, Brazil
}

\begin{tabular}{|c|c|}
\hline \multicolumn{2}{|c|}{ Rezende LC' } \\
\hline \multicolumn{2}{|c|}{ Oliveira TM" } \\
\hline \multicolumn{2}{|c|}{ Teixeira CM"II } \\
\hline \multicolumn{2}{|c|}{ Oliveira PRII† } \\
\hline \multicolumn{2}{|c|}{ Martins NRS" } \\
\hline \multicolumn{2}{|c|}{ Cunha LMIV } \\
\hline 1 & $\begin{array}{l}\text { Ministério da Agricultura, Pecuária e } \\
\text { Abastecimento (LANAGRO-MG), Pedro } \\
\text { Leopoldo, MG, Brasil. }\end{array}$ \\
\hline & $\begin{array}{l}\text { Escola de Veterinária, Universidade Federal } \\
\text { de Minas Gerais, Brasil. }\end{array}$ \\
\hline & $\begin{array}{l}\text { Fundação Ezequiel Dias, Belo Horizonte, } \\
\text { MG, Brasil. }\end{array}$ \\
\hline & $\begin{array}{l}\text { Universidade Federal de Ouro Preto, Ouro } \\
\text { Preto, MG, Brasil. }\end{array}$ \\
\hline
\end{tabular}

\section{Mail Address}

Corresponding author e-mail address Tiago Mendonça de Oliveira

Escola de Veterinária da UFMG, Av. Antônio Carlos 6627 Caixa Postal 567, campus Pampulha da UFMG CEP: 31270-901. Belo Horizonte, MG, Brasil.

Phone: (31)98658-7122

Email: tiago0725@gmail.com

\section{-Keywords}

Flies, Laying hens, Management of poultry manure.

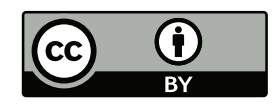

Submitted: 19/October/2017

Approved: 28/January/2018

\section{ABSTRACT}

Aspects related to epidemiology of flies belonging to Fannia genus were studied in order to determine predisposing factors for its occurrence in layer hens houses of commercial farms in the state of Minas Gerais, Brazil. An observational, analytical and sectional survey was conducted to verify major epidemiological aspects associated to infestations. This research was accomplished starting from an adapted secondary database of and structured with information on the presence and absence of ectoparasites and arthropods, characteristics of chicken houses, the poultry, type of facilities, geographical location and the management. The study was conducted in four hundred and thirty one houses located in forty three farms visited in 2012 year in the state of Minas Gerais. Ten farms (23.25\%) and sixty eight houses (15,77\%) were observed the presence diptera belonging to Fannia genus. The specie Fannia admirabilis was found in four farms (9,30\%), Fannia albitarsis in two farms $(4,65 \%)$ and only in one farm $(2.32 \%)$ was observed the presence of Fannia canicularis. For three farms $6,98 \%$ was no possible to identify the species only Fannia genus. The epidemiological aspects for the occurrence of these flies were investigated using Poisson regression models. Characteristics such as farm, city of farm, presence of Histeridae beetles, type of facility (cage, on the floor with or without bedding) and the existence of mechanical removal of manure were associated with the occurrence of Fannia spp.

\section{INTRODUCTION}

In traditional egg production systems, laying hens are housed in high densities, leading to accumulation of manure under the cages, making it an excellent substrate for the development of synanthropic flies (Lopes et al., 2008). Environments modified by humans are associated with the presence synanthropic diptera. Flies utilize feed residues, dead birds, broken eggs, and accumulated excreta for growth and survival (Nuorteva, 1963; Peck \& Anderson, 1970; Prado, 2003). Muscoid diptera are considered important vectors of human and animal pathogens due their eating and reproductive habits and synanthropic behavior. Moreover, those arthropods are capable of moving and flying for long distances (Barreiro et al., 2013; Blaak et al., 2014).

Axtell (1999) describes that, among the flies of the Fannia genus, the most widespread species is Fannia canicularis, which may be a major pest in some regions. The biological cycle from egg to the adult stage of this fly requires 15-30 days, which is longer than that of the Musca domestica. Fannia genus larvae are frequently found in the manure together with other fly larvae. This species often flies slowly in circles inside poultry houses, are able to disperse to neighboring farms, and may harbor human and avian disease microorganisms. A few other species of Fannia with very similar appearance and behavior 
Rezende LC, Oliveira TM, Teixeira CM, Oliveira PR, Martins NRS, Cunha LM
Occurrence and Epidemiology of Fannia Spp. (Diptera: Fanniidae) in Laying Poultry Farms in State of Minas Gerais, Brazil as F. canicularis are found in chicken houses in some regions and are most readily differentiated by details of larval spine arrangement and type.

Muscoid flies, especially those belonging to the Muscidae, Fanniidae and Anthomyiidae families, are among the insects most commonly associated with human and animal production environments (Carvalho et al., 2002). Many fly species associated with manure in egg-laying farms have been previously described (Axtell \& Arends, 1990), because the accumulation of waste under the laying cages provides a favorable environment for the development of diptera of the Fannia genus. In Brazil, F. canicularis was detected in poultry farms in the municipality of Pelotas, state of Rio Grande do Sul (Bicho et al., 2004) and the species F. trimaculata and F. pusio were described in municipalities of the state of São Paulo (Bruno et al., 1993). In the state of Minas Gerais, Lomônaco \& Prado (1994) captured some diptera species, including F. trimaculata and F. pusio, in a layer farm of the municipality of Uberlândia. There are few studies on the biology, ecology, and predisposing factors for the presence of these arthropods in layer farms, as well as on the factors related to their infestation epidemiology. Most studies on flies in Brazilian poultry farms evaluate species such as M. domestica and Chrysomya spp. (Lopes et al., 2007). Lopes et al. (2008) verified the presence of other fly species in a layer farm in the state of São Paulo, including Drosophila repleta, M. domestica, Ophyra spp., Hermetria illucens, F. canicularis, Chrysomya megacephala, as well as Sepsidae species.

Considering the few studies on the occurrence of Fannia ssp. in layer farms and the economic importance egg production in Brazil, this study aimed at investigating the occurrence of Fannia spp. in layer farms in the state of Minas Gerais and analyzing the epidemiological aspects and factors that may favor the presence of these flies.

\section{MATERIAL AND METHODS}

This survey was performed using the secondary databases of Cunha (2013) and Rezende (2014), which were adapted to include information on ectoparasites and arthropods, layer house characteristics, chicken, the type of facilities, geographic location, and management practices. The study was conducted in commercial laying chicken farms in the state of Minas Gerais, which is located in the southeastern region of Brazil and has an area of 586,519.727 km², characterized by the large range of climatic conditions.
A number of 431 poultry houses belonging to 43 layer farms were visited between March to June 2012. House relativehumidity and temperaturewere measured during the visits. Considering that climatic variations may influence the occurrence of ectoparasites, farms located in areas which environmental temperatures may be below $5^{\circ} \mathrm{C}$ or above $40^{\circ} \mathrm{C}$ were not visited.

The number of layer farms in each region of the state was determined using the georeferencing data of the Agricultural Institute of Minas Gerais (IMA) (Figure 1). The ratio between the numbers of layer farms registered in each IMA administrative region and the total number of commercial layer farms in the state of Minas Gerais were used to stratify the sample. The map showing the evaluated regions was previously published by Cunha (2013). The number of layer houses per farm ranged from 1 to 40, with an average of 10 (standard deviation $=5.49$ ). In 41 farms, layers were housed in cage systems. Out of the 431 houses surveyed, 29 were used for rearing replacement pullets. Sample size was calculated as a conglomerate (i.e. type of cluster) of active poultry houses, considering $50 \%$ hypothetical prevalence of arthropod pests or ectoparasites, 5\% standard error, and a finite number of farms.

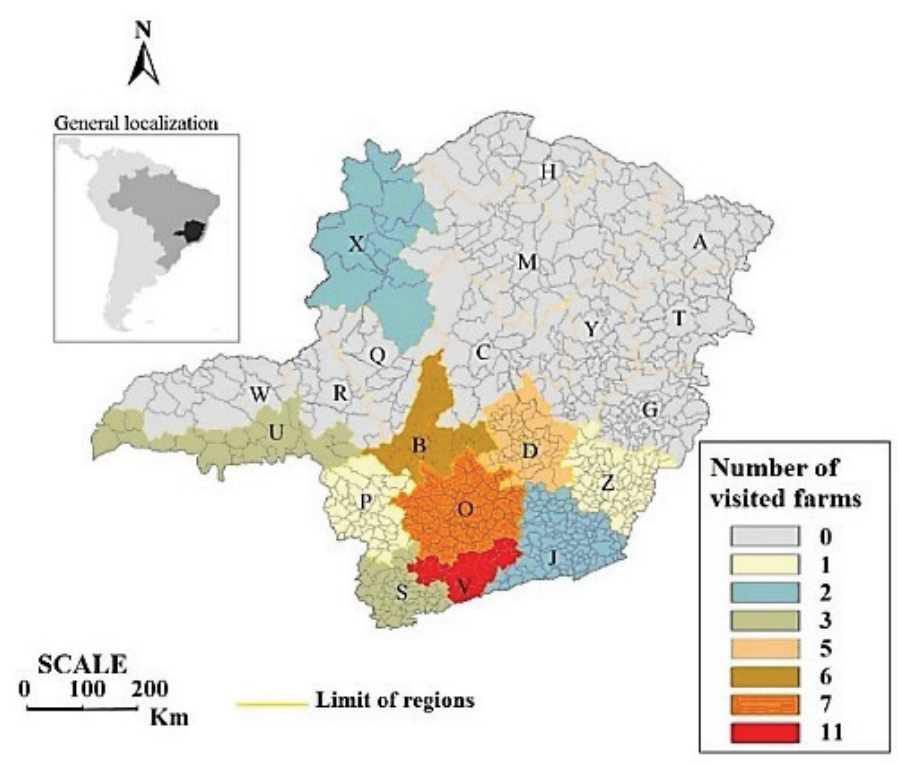

Figure 1 - Map with the number of farms visited in regions according the Agricultural Institute of Minas Gerais (IMA), Minas Gerais, Brasil. A- Almenara; B- Bambuí; C- CurveIo; D- Belo Horizonte; G- Governador Valadares; H- Janaúba; J- Juiz de Fora; M- Montes Claros; O- Oliveira; P- Passos; Q- Patos de Minas; R- Patrocínio; S- Pouso Alegre; T- Teóflo Otoni; U- Uberaba; V-Varginha; W- Uberlândia; X- Unaí; Z- Viçosa.

Simultaneously, different risk and protective factors for the occurrence (presence or absence) of Fannia spp. infestation were evaluated using Poisson regression models and considering layer houses as the sampling unit (Dohoo et al., 2003). The intensity 
of Fannia spp. infestation in the layer house or in the poultry was not measured. The following variables were evaluated: geographic location (region, municipality), farm type (egg production, replacement pullet rearing, broiler production), production system (cages, on the floor with or with no litter), number of birds per house (n), housing density (birds $/ \mathrm{m}^{2}$ ), biological parasite control (absence or presence), manure removal (presence or absence), and the presence Diptera predatory arthropods (Coleoptera as Hololepta spp., Euspilotus spp, Carcinops spp., Dermestes ater and Histeridae beetles). The Poisson regression models were built using the software Stata ${ }^{\circledR} 12.0$ (Dohoo et al., 2003).

Fly samples were collected during the inspection of the poultry house with the aid of open plastic bags containing an attractive insecticide. Bags were sealed and submitted to the Ectoparasitosis Laboratory of the School of Veterinary Medicine of the Federal University Minas Gerais, where they were stored at $-20 \pm 2{ }^{\circ} \mathrm{C}$ until processing.

The adult specimens of Fannia spp. and of other arthropods were examined under a stereoscopic microscope (Olympus, Japan) and identified according to their morphological characteristics utilizing identification keys (Mcalpine et al., 1987; Carvalho, et al., 2002; Bouchard, et al., 2005; Wendt \& Carvalho, 2009; Bouchard et al., 2011; Triplehorn \& Norman, 2011).

The variables included in Poisson regression models were first selected using the Chi-Square test, Fisher's Exact test or Univariate Logistic Regression for removal of confounding variables and those with significance higher than $15 \%(p>0.15)$. The highest coefficients of determination $\left(R^{2}\right)$ and the analysis of the Incidence Rate Ratios (IRR) confidence intervals (95\% significance - $95 \% \mathrm{Cl}$ ) were used to select the variables to be included in the models. Variables with IRR values lower than 1.0 are considered protection factors and those with values higher than 1.0 are risk factors. Variables with significant IRR $(p \leq 0.005)$ or which removal would disrupt the general model were included. The goodness of fit of the Poisson regression model was verified by the Pearson's Chi-Square test.

\section{RESULTS AND DISCUSSION}

The presence of flies of the Fannia genus in 10 $(23.25 \%)$ poultry farms, and the species $F$. admirabilis, $F$. albitarsis, and $F$. canicularis were identified (Table 1). However, Fannia species were not detected in three farms (6.98\%). These results indicate different Fannia species were present in laying poultry farms and are relevant when considering the health aspects of egg production. Other studies have also reported the presence of Fannia spp. in poultry facilities (Povolny, 1971; Lopes et al., 2007). Lomônaco \& Prado (1994), in a survey conducted in poultry farms in Uberlândia, Minas Gerais, verified the presence of $F$. pusio and $F$. trimaculata. In addition to these species, F. canicularis also was found in poultry farms in the state of São Paulo (Bruno et al., 1993). Monteiro \& Prado (2000) also reported the presence of $F$. pusio in farms located in São Paulo. In the United States, F. canicularis and F. femoralis were associated with poultry environments (Anderson \& Poorbaugh, 1964; Axtell \& Arends, 1990) and in Argentina, F. albitarsis was associated with poultry production environments (Perotti 1998).

Table 1 - Frequency of observations of Fannia spp. in commercial layer flocks in state of Minas Gerais, Brazil, 2012.

\begin{tabular}{lcc}
\hline Flies & Number of positive houses & Frequency \\
\hline Fannia ssp. & 68 & $15.77 \%$ \\
Fannia admirabilis & 40 & $9.30 \%$ \\
Fannia albitarsis & 20 & $4.65 \%$ \\
Fannia canicularis & 10 & $2.32 \%$ \\
\hline
\end{tabular}

Table 2 shows the variables selected during screening of epidemiological determinants of the occurrence of Fannia spp. flies in poultry farms of Minas Gerais. The region variable was removed from the final model because the preliminary multivariate statistical

Table 2 - Variables potentially associated with the occurrence by Fannia spp. selected by univariate statistical tests $(p<0,15)$.

\begin{tabular}{ll}
\hline Characteristic & $p$ value \\
\hline Region & $0.000^{*}$ \\
\hline Municipality & $0.000^{\#}$ \\
\hline Farm & $0.000^{\#}$ \\
\hline Production system (Cage, on the floor with or without bedding) & $0.042^{*}$ \\
\hline Number of birds per house & $0.027^{\#}$ \\
\hline Housing density (number of chickens per cage) & $0.002^{*}$ \\
\hline House type (laying hens, replacement pullets or broiler) & $0.180^{*}$ \\
\hline Use of selective insecticides for fly control & $0.000^{*}$ \\
\hline Presence of biological control & $0.000^{*}$ \\
\hline Use of mechanical removal of manure & $0.008^{*}$ \\
\hline Presence of Hololepta spp. & $0.013^{*}$ \\
\hline Presence of Euspilotus spp. & $0.113^{*}$ \\
Presence of Carcinops spp. & $0.008^{*}$ \\
\hline Presence of Dermestes ater & $0.111^{*}$ \\
Presence of Histeridae beetles & $0.000^{*}$ \\
\hline Presence of Chrysomya putoria & $0.002^{*}$ \\
\hline Presence of Uropodidae mites in manure & $0.000^{*}$ \\
\hline *Chi- square test/ Fisher's Exact test. \\
\#Univariate logistic regression.
\end{tabular}


Rezende LC, Oliveira TM, Teixeira CM, Oliveira PR, Martins NRS, Cunha LM
Occurrence and Epidemiology of Fannia Spp. (Diptera: Fanniidae) in Laying Poultry Farms in State of Minas Gerais, Brazil models showed it was not significant $(p=0.377)$, which suggests that the distribution of poultry farms in different regions of the state of Minas Gerais is not a determining factor for the occurrence of infestations of these flies. On the other hand, the municipality where the farms are located $(p=0.000)$ significantly influenced the occurrence of Fannia spp., and was included in the final model, indicating higher risk of infestation in some municipalities than in others (Table 3). The preliminary analysis showed the variable poultry farm significantly influenced Fannia spp. occurrence and was maintained in the final model (Table 3). Poultry farm was considered as a protective factor, with an IRR of 0.86 , indicating that some farms presented infestation risk probably due poultry farm specificities, such as management practices, manure removal, geographic location and application of ectoparasite control. Poisson regression models were built considering the clustering relationship between region, farm, and house, but they did not show appropriate fit. Therefore, it was not possible to evaluate with more details the influence of geographical distribution on the epidemiology of flies of the Fannia genus.

Table 3 - Variables associated with the occurrence of Fannia spp. in commercial layer flocks in state of Minas Gerais, Brazil, 2012.

\begin{tabular}{|c|c|c|c|c|}
\hline Characteristic & $\begin{array}{l}\text { Incidence Rate } \\
\text { Ratio }\end{array}$ & Confidence II & Interval (95\%) & $p$ Value \\
\hline City & 1.38 & 1.26 & 1.51 & 0.000 \\
\hline Farm & 0.86 & 0.80 & 0.91 & 0.000 \\
\hline $\begin{array}{l}\text { Presence of } \\
\text { Histeridae beetles }\end{array}$ & 0.016 & 0.0024 & 0.107 & 0.000 \\
\hline $\begin{array}{l}\text { Type of } \\
\text { establishment }\end{array}$ & 0.43 & 0.22 & 0.83 & 0.012 \\
\hline $\begin{array}{l}\text { Use of mechanical } \\
\text { removal of manure }\end{array}$ & 0.26 & 0.11 & 0.62 & 0.002 \\
\hline
\end{tabular}

Number of valid observations: 431.

$p$-value of Pearson Qui-Square test for goodness of fit: 1.000 .

Pseudo R² (pseudo coefficient of determination): 0.2989.

Farm type ( $p=0.992)$ and housing density ( $p=0.652)$ were not significant in the preliminary analysis and were removed from the final model. The confidence interval of the Incidence Rate Ratio obtained for the total number of birds per house (IRR $=0.99$; $95 \% \mathrm{Cl}=0.99992$ to $0.99993 ; p=0.012)$ allowed its classification as a protective factor. However, this result is not biologically plausible, as a higher number of hens increases the amount of manure produced, which consequently increases possibility of attraction and development of flies. As the number of hens per farm was expected to be a risk and not a protective factor, it was considered as confounding variable and was excluded from the statistical models.
The use of selective insecticides was removed from the final model due to the lack of significance $(p=0.994)$ in the preliminary analysis. The application of biological control ( $p=0.993)$ and the presence of arthropods, such as Hololepta spp. $(p=1.000)$, Euspilotus spp. $(p=0.999)$ and Carcinops spp. $(p=0.998)$, that could be involved in this process were not significant in the preliminary regression models and were removed from the final model. However, when the presence of these beetles was analyzed as a group (Histeridae family), it showed to be a significant $(p=0.000)$ determinant for the occurrence of Fannia spp. Therefore, the presence of Histeridae beetles is a protective factor against the infestation by these flies (Table 3), that is, in houses where the presence of these beetles was detected, Fannia spp. occurrence was about of 62.5 times smaller. This may be explained by the possible predation of Fannia spp. eggs and larvae by Histeridae beetles in the manure, as reported for other fly species, such as M. domestica and Chrysomya spp. (Hulley \& Pfleiderer, 1988; Lopes et al., 2007; Pinto \& Ribeiro, 2011).

The presence of Uropodidae mites (IRR $=2.65 ; 95 \%$ $\mathrm{Cl}=1.57$ to $4.45 ; p=0.000$ ) was wrongly characterized as a risk factor for the occurrence of Fannia spp. due to values of the confidence interval presented. However, an IRR with a confidence interval lower than one (protection factor) was expected as species of this family of mites are often reported as predators of dipteral eggs and larvae (Axtell \& Arends, 1990; AlDulaimi, 2002; Rodrigueiro \& Prado, 2004). Therefore, the presence of Uropodidae mites was considered as a confounding variable, which resulted in it exclusion of the final regression model. The variables presence of the beetle Dermestes ater $(p=0.798)$ and of the diptera C. putoria $(p=0.284)$ were not significant in the preliminary Poisson regression analysis and were removed from the general model.

Manure removal was considered as a protective factor against infestations by Fannia genus (Table 3), indicating the risk of occurrence of Fannia spp. was 3,8 time smaller when this practice was applied. Manure removal dramatically and immediately reduces the volume of substrate for fly eggs, larvae, and adult development, disrupting fly biological cycle. Peck \& Anderson (1970) also reported that manure availability is an important factor for the occurrence of flies in poultry establishments.

Preliminary analysis showed significant influence of house type (laying hens, replacement pullets; $p=0.180$ ) was and remained in the final regression model (Table 3), which indicated that replacement pullet houses had about 2.3 times lower risk of being infested with Fannia spp. than layer houses. Differences among facilities (farms with manual egg collection, farms with 
Rezende LC, Oliveira TM, Teixeira CM, Oliveira PR, Martins NRS, Cunha LM
Occurrence and Epidemiology of Fannia Spp. (Diptera: Fanniidae) in Laying Poultry Farms in State of Minas Gerais, Brazil automated egg collection, replacement pullets) and management practices may account for these results.

\section{CONCLUSIONS}

The results show that flies of the genus Fannia spp. frequently infest layer farms in the state of Minas Gerais. House type, municipality where farms are located, and poultry farm significantly influence the epidemiology of infestations. The presence of Histeridae beetles in the manure and manure removal are protective factors against the occurrence of Fannia species. Therefore, adequate monitoring and manure management, as well as the possible predation by Histeridae beetles may aid the control of Fannia spp. infestations in poultry farms.

\section{ACKNOWLEDGEMENTS}

We are indebted to Instituto Mineiro de Agropecuária (IMA) and the owners of poultry farms who authorized the research. We thank the financial support and scholarships provided by Conselho Nacional de Desenvolvimento Científico e Tecnológico (CNPq), Fundação de Amparo à Pesquisa do Estado de Minas Gerais (FAPEMIG), Coordenação de Aperfeiçoamento de Pessoal de Nível Superior (CAPES) and the Federal University of Minas Gerais.

\section{REFERENCES}

Al-Dulaimi SI. Predation by the mite Macrocheles glaber (Müller) (Acarina:Macrochelidae) on the house fly Musca domestica L. with some notes on its biology. Bulletin of the Iraq Natural History Museum 2002;9(4):7-11.

Anderson JR, Poorbaugh $\mathrm{JH}$. Observations on the ethology and ecology of various Diptera associated with northern California poultry ranches. Journal of Medical Entomology 1964;1(2):131-147.

Axtell RC, Arends JJ. Ecology and management of arthropod pests of poultry. Annual Review of Entomology 1990;35:101-126.

Axtell RC. Poultry integrated pest management:status and future. Integrated Pest Management Reviews 1999;4:53-73.

Barreiro C, Albano H, Silva J, Teixeira P. Role of flies as vectors of foodborne pathogens in rural areas. ISRN Microbiology; 2013. Available from: <http://dx.doi.org/10.1155/2013/718780> eCollection 2013.

Bicho CL, Almeida LM, Ribeiro PB, Júnior PS. Flutuação de Diptera em granja avícola Pelotas, Rio Grande do Sul, Brasil. Iheringia:Série Zoológica 2004;94(2):205-210

Blaak H, Hamidjaja RA, van Hoek AH, de Heer L, de Roda Husman AM, Schets FM. Detection of extended-spectrum beta-lactamase (ESBL)producing Escherichia coli on flies at poultry farms. Applied and Environmental Microbiology 2014;80(1):239-246.

Bouchard P, Lawrence JF, Davies AE, Newton AF. Synoptic classification of the world Tenebrionidae (Insecta:Coleoptera) with a review of family group names. Annales Zoologici 2005;55(4):499-530.

Bouchard P, Yves Bousquet Y, Davies AE, Alonso-Zarazaga MA, Lawrence JF, Lyal CHC, et al. Family-group names in Coleoptera (Insecta). ZooKeys $2011 ; 88: 972$
Bruno TV, Guimarães JH, Santos ÂMM, Tucci EC. Moscas sinantrópicas (Diptera) e seus predadores que se criam em esterco de aves poedeiras confinadas no Estado de São Paulo, Brasil. Revista Brasileira Entomologia $1993 ; 37(3): 577-590$

Carvalho CJB, Moura MO, Ribeiro PB. Chave para adultos de dípteros (Muscidae, Fanniidae, Anthomyiidae) associados ao ambiente humano no Brasil. Revista Brasileira Entomologia 2002;46(2):107-114.

Cunha LM. Aspectos epidemiológicos relacionados à ocorrência de ácaros hematófagos em granjas comerciais de postura no Estado de Minas Gerais e avaliação de armadilhas para captura de Dermanyssus gallinae (Acari:Dermanyssidae) (De Geer, 1778) [tese]. Belo Horizonte (MG): Escola de Veterinária Universidade Federal de Minas Gerais; 2013.

Dohoo I, Martin W, Stryhn H. Veterinary epidemiologic research. Charlottetown: Atlantic Veterinary College; 2003. p.446-461.

Hulley PE, Pfleireder M. The Coleoptera in poultry manure-potential predators of house flies, Musca domestica Linnaeus (Diptera:Muscidae). Journal of the Entomology Society of Southern Africa 1988;51:17-29.

Lomônaco C, Prado AP. Estrutura comunitária e dinâmica populacional da fauna de dípteros e seus inimigos naturais em granjas avícolas. Anais da Sociedade Entomológica do Brasil 1994;23(1):71-80.

Lopes WDZ, Costa FH, Lopes WCZ, Balieiro JCC, Soares VE, Prado AP. Artrópodes associados ao excremento de aves poedeiras. Neotropical Entomology 2007;36(4):597-604

Lopes WDZ, Costa FH, Lopes WCZ, Balieiro JCC, Soares VE, Prado AP. Abundância e sazonalidade de dípteros (Insecta) em granja avícola da região nordeste do estado de São Paulo, Brasil. Revista Brasileira de Parasitologia Veterinária 2008;17(1):21-27

Mcalpine JF, Peterson BV, Shewell GE, Teskey HJ, Vockeroth JR, Wood DM. Manual of nearctic diptera [monograph 28]. Ottawa: Research Branch Agriculture Canada; 1987. v.2; p.1332.

Monteiro MR, Prado AP. Ocorrência de Trichopria sp. (Hymenoptera:Diapriidae) atacando pupas de Chrysomya putoria (Wiedemann) (Diptera:Calliphoridae) na granja. Anais da Sociedade Entomológica do Brasil 2000;29(1):159-167.

Nuorteva P. Synanthropy of blowflies (Diptera, Calliphoridae) in Finland. Annales Entomologicae Fennicae 1963;25(1):1-49.

Peck JH, Anderson JR. Influence of poultry manure removal schedules on various diptera larval and selected arthropod predators. Journal Economic Entomology 1970;63(1):82-90.

Perotti A. Moscas sinantrópicas (Díptera:Muscidae y Fanniidae) associadas a producciones avícolas del centro-sudestes bonarense. Natura Neotropicalis 1998;2(29):145-154.

Pinto DM, Ribeiro PB. Flutuação populacional de Euspilotus rubriculus (Marseul) (Coleoptera:Histeridae) em granja avícola em Pelotas, RS. Arquivos do Instituto Biológico 2011;78(4):625-628.

Povolny D. Flies and diseases: ecology, classification and biotic association. Princeton: Princeton University Press; 1971. p.83.

Prado AP. Controle das principais espécies de moscas em áreas urbanas [palestra]. Biológico 2003;65(1/2):95-97.

Rezende LC. Aspectos epidemiológicos de Megninia spp. (Acari: Analgidae) e malófagos (Insecta: Phthiraptera) na avicultura de postura de Minas Gerais (2012) [dissertação]. Belo Horizonte (MG): Escola de Veterinária Universidade Federal de Minas Gerais; 2014

Rodrigueiro TSC, Prado AP. Macrocheles muscaedomesticae (Acari, Macrochelidae) and a species of Uroseius (Acari, Polyaspididae) phoretic on Musca domestica (Diptera, Muscidae): effects on dispersal and colonization of poultry manure. Iheringia Série Zoologia 2004;94(2):181-185.

Triplehorn CA, Norman FJ. Estudo dos insetos. São Paulo: Cengage Learning; 2011. 816p.

Wendt LD, Carvalho CJB. Taxonomia de Faniidae (Diptera) do sul do Brasil - II: novas espécies e chave de identificação de Fannia RobineauDesvoidy. Revista Brasileira de Entomologia 2009;53(2):171-206. 
